\title{
Camille Claudel: a revulsion of nature The art of madness or the madness of art?
}

\author{
Camille Claudel: uma revolta da natureza \\ Arte da loucura ou loucura da arte?
}

\author{
Othon Bastos
}

T

he artistic work of children, primitive people and mental patients is generally referred to as arte ínsita, in Portuguese, a term which stems from Latin in situ (Suassuna, 1996). However, art produced by mental patients has also been termed psychopathological art, an expression which greatly displeases me for there is no such thing as sick, psychotic or mad art and neither can a work of art be said to be mentally ill. For this reason, I would rather refer to it by the scholarly term previously referred.

In the context of art produced by the mentally ill, it is extremely important to tell the artist - amateur or professional - who has exercised his technical skills from the insane that eventually became an artist, i.e., a psychiatric patient who either spontaneously or through occupational therapy started producing plastic arts or literary works. It is evident that both the works produced before the presentation of any pathological symptoms and the ones produced after them provide clear clues as to the morbid processes which have been developing in the patient's mind (conscious and unconscious psychic life).
After all, every artistic creation allows scope for individual expression, always present in the relationship between creation and creator. The main objective of the occupational therapeutic practices for mentally ill patients is to give way to self-expression through drawing, painting or modeling, for example.

In this spirit, Nise da Silveira, whose $100^{\text {th }}$ birthday is now being celebrated, organized the Museum of the Unconscious in a psychiatric center in the 1940's. This museum was moved to Casa das Palmeiras, in Rio de Janeiro, and in the middle of the 1950's its collection was exhibited in the World's First Congress of Psychiatry in Paris, which made it renowned. Similarly, different psychiatric services use to present their collections during scientific journeys, meetings and psychiatric congresses. Juqueri's collection, organized by Professor Mario Yahn together with Osório César, an eminent psychoanalyst from Paraíba who chose to live in São Paulo, particularly stands out. The latter took part in the Modernist Week of 1922 and his work was the subject of an important

\footnotetext{
Universidades Federal e Estadual de Pernambuco (UFPE/UPE) (Bastos 0)

Conference presented at XVIII Congresso Brasileiro de Psiquiatria, Belo Horizonte, October 2005.

Recebido

07-08-06

Aprovado

01-09-06

Correspondence to: Othon Bastos

Rua Amazonas, 154/601 - Boa Viagem - 51011-020 - Recife-PE - Tel.: (81) 33250399

e-mail: othon@elogica.com.br
} 
doctoral thesis by Maria Heloísa C. T. Ferraz in 1988. The Brazilian Association of Psychiatry itself, in collaboration with a pharmaceutical company, has maintained in its annual congress a saloon for the exhibition of psychiatric patients' works of art. A judging commission mostly constituted by critics of art, plastic artists and intellectuals who show interest in the subject evaluates and awards prizes to the best works.

The inappropriately named psychopathological art has been the object of a vast literary and artistic production such as critical essays, catalogues, art albums and anthologies. Strictly speaking, art produced by psychiatric patients with no artistic initiation greatly differs from art produced by accomplished artists who eventually became mentally ill. The production of the former are very close to the one by the primitives, by the naives, whereas the production of the latter keeps the characteristics of the school the artist has been linked to.

Therefore, I also find the expressions that make up the word play the art of madness and the madness of art inappropriate. The art of madness is nothing else than psychopathological art. The madness of art is a subject I know nothing of, though I do show up at every São Paulo's Biennial Arts Exhibition and try to keep up with local, national and international artistic movements.

To paraphrase Oscar Wilde's saying in his preface to The Picture of Dorian Gray, I would add there is no such thing as mad art, but just good or bad art, art with or without esthetic value. Though lacking artistic value, psychiatric patients' works lend themselves to psychopathologic or psychoanalytical studies and interpretations, which help bridge the gap between creature and creator.

Believing that each and every psychotic patient is a potential plastic or literary artist would be analogous to believing that people deprived of sight would potentially be exceptional musicians, or excellent interpreters. Only the talented psychotics will produce genuine works of art. The majority will just create works of great therapeutic, psychopathologic or phenomenological importance, but of reduced artistic value.

As José Lucena declared about Kal Jasper's book Genio y Locura (Genius and Madness), Van Gogh, Holderlin, Strindberg and Swedenborg created notable plastic and literary works of art even though they were schizophrenic sufferers and not because they were mentally affected. This list could be made longer if we added the famous Henri de Toulouse Lautrec (chronic alcoholism and nervous syphilis), Nietzsche (general progressive paralysis), Lima Barreto (alcohol dependence), Hélio Feijó, Schumann (PMD) and many others.

When Camille Claudel's symptoms became really severe she was diagnosed as schizophrenic. In 1905, she started destroying her own pieces of work and was no longer able to produce anything new during all the time (from her father's death in 1913 to her own death in 1943) she was in hospital.

In addition to $\mathrm{K}$. Jaspers, many other authors and psychiatric teachers have also dedicated themselves to the theme, as E. Kretschmer, (Hombres Geniales), VallejoNajera (Loucos Egrégios), Goodwin and Jamison (intellectual production of bipolar affective disorder).

\section{The master, the pupil and Rodin's studio}

Nothing more natural in the realm of plastic arts than a less-than-famous pupil who plays the muse or assists his master accomplish a great work. So it was in the past with the masters of the Flemish school of painting; with the works done by Michelangelo and Raphael in the Vatican or, in Brazil, with Aleijadinho's soapstone works in the courtyard of Bom Jesus do Matosinhos Church or with his wood sculptures in the 5 Dos Passos Chapels. So it was with Rodin and Camille Claudel. Therefore, traces of reciprocal influence in Rodin's and his notable artist pupil's work are noted. Such artistic interchange was clearly acknowledged by each. Rodin once declared: "I have shown her where to find gold, but the gold she finds belongs to her" (Cassar, 1987; Gaudichon, 1984; Pinet, 1984; Vilain, 1996) and Camille, commenting about Les Causeuses and La Vague, two of her most original works, in a letter addressed to her brother Paul in 1893 declared: "You see that these works are no longer Rodin's", clearly acknowledging she had been indebted to Rodin until then.

These two testimonies speak for themselves. Rodin and Camille were collaborators, and as such, worked together, but sometimes they worked apart. By the way, it is worth remembering that Rodin, 24 years her elder, was already renowned when they met and a year later became her lover. Appropriation, if any there was, I risk saying, was reciprocal, a common thing between collaborators.

In the magnificent park of sculptures in the center of Oslo - a most beautiful, extensive and creative work - by the Norwegian Gustav Vigeland, another of Rodin's pupil, one feels both the master's and Camille's influence. This is particularly true for the bronze figures: a couple and a vegetable around the fountain, in which the three realms of nature are mixed.

\section{Psychopathologic approach to Camille Claudel}

To begin with, some biographical data is imperative. Camille Claudel was born in Villeneuve-sur-Fère, Ardennes, in December 1864 to Louis Prosper - a public officer who appreciated the classics and stimulated his children - and his wife, Louise Athanaïse - not a very sensible or affectionate (she never kissed her children) mother. Born after the death of the first child, a boy, Camille was rejected from the start for having broken with her mother's expectations of another male baby. Very significantly, she was given an ambiguous name with regard to sex. Camille would also have a sister - a piano player and her mother's favorite - who was also named Louise, and a brother, Paul, a successful diplomat, playwright and poet.

From a very early age, Camille got along better with her father and brother. At the same time, she dedicated herself to modeling several historical figures, her brother and villagers (The Old Hélène) in clay. Her teacher, an artist called Alfred Boucher, advised the family to move to Paris, where Camille began to study at the Colarossi Academy. 
There she met Paul Dubois, director of the National School of Beaux Arts, who presented her to Auguste Rodin in 1882. In 1883, she started working at Rodin's studio on Rue de l'Université. Her mother never gladly agreed with her daughter's professional choice, somewhat uncommon for women at that time.

Rodin was in a very productive phase, having been commissioned to make The Gates of Hell and The Bourgeois of Calais. From a substitute paternal figure, clearly Oedipal, Rodin becomes her master and passionate lover, a love to which she fully reciprocated. Mutual admiration and artistic affinity sprang up. Camille would declare later, "He who does not realize the greatness of the creator of The Gates of Hell is either for want of greatness in himself or for inability" (Jarassé, 1993; Pinet, 1984; Vilain, 1996).

The apprentice was very skilled in the art of handling different materials with which she created pieces of work endowed with movement and rich details, particularly hands and feet. Rodin mostly dedicated himself to the exact reproduction of his models. Professionally, they complemented one another. Camille became Rodin's first female apprentice, favorite model and also the first woman to carve masculine nudes. He, however, maintained his liaison with Rose Beuret, a former model whom he would marry at the end of his life. No matter the rapture into which Rodin and Camille lived for five years, the trips and the moments together in Folie Naubourg, an ancient cottage that had served as George Sand's and Alfred de Musset's love nest, the sculptor could never decide marrying his talented mistress. Camille reached the point of making satirical works involving Rodin and Rose Beuret (Le Systeme Cellulaire, Le Réveil et Collage). Some years later, after having an abortion or more than one, according to some authors, and feeling he would never abandon Rose to marry her, she decided to move to Boulevard d'Italie and live by herself. It is then that the first signs and symptoms appeared of the mental illness that would blight up her existence until the end of her days. She began, however, to dedicate herself more closely to her own work. This is the period of La Valse (1893); Clotho (1893); Les Causeuses ou La Confidence, both in onyx, and finally the extremely expressive The Age of Maturity, which was accepted for the Annual Arts Saloon in 1899 (Monique, 1984). In 1898, she definitely breaks with her love attachment to Rodin. She moved to Quai Bourbon, her last workshop, in
1899, where she remained until 1913 when her mother and brother committed her to Ville Évrard, a mental hospital. In the meantime, in 1905, Eugène Blot promoted an individual exhibition of Camille's work in his Gallery. Some critics of art reacted violently to the exhibition and one of them, from Le Petit Quotidien, referred to the artist as "one of the glories and the shame of the country". Her very brother, Paul, becomes ashamed of his sister's physical and moral decadence. In 1905, Camille created her last sculpture, Perseus and the Gorgon. From then on, at 42 years of age, with the aggravation of her mental condition, she lived secluded and destroyed most of her statues.

From the phenomenological point of view, Camille Claudel began to present the first paranoid ideas of a persecutory type at 29 years of age, in 1893, right after Rodin's amorous and affective rejection, which would have aroused old feelings due to her mother's lifelong rejection of her. The triangular relationship became her theme and was very well depicted in The Age of Maturity and in other works such as The Abandonment and Vertumnes and Pomona inspired in Sankoutala. In The Age of Maturity, Rodin led by Death in the figure of Rose Beuret is followed by a mendicant, the very Camille.

She felt persecuted, avoided everyone, destroyed her creations and had them buried, drank too much and disappeared for long periods of time. In addition to all this, she was ruined, deprived from the least comfort and also in physical misery, which she had imposed on herself. When she was found by the doctor who committed her, she was living in extreme poverty along with street cats, always dressed in a white gown, disheveled hair, crying out curses on Rodin, the scoundrel. She feared getting poisoned by him. Likewise, in hospital, she feared food without skin. During the 30 years of her confinement, she did not create a single work of art.

She was diagnosed either as a Morel and Kraepelin dementia praecox sufferer or as a Bleuler schizophrenia sufferer. It is highly improbable she was a Pick or Alzheimer sufferer. All that is left from this period are her letters to friends and family. Her brother went to see her only a few times. Her sister, her brother-in-law and her mother never once visited her. Rodin, who died in 1917, sent her some money. In October 1943, her tragic and rich life came to an end at the Psychiatric Hospital in Montdevergues, Vaucluse.

\section{References}

Barros Leal W. A vida trágica da escultora Camille Claudel. Continente Multicultural, 4(48), 37-48, 2004

Cassar J. Dossier Camille Claudel. Paris: Librairie Séguier; 1987.

Coleção Arte Wyeth. Camille Claudel. São Paulo: Lemos Editorial e Gráficos LTDA; s/data.

Ferraz MHCT. Arte e Loucura: Limite do Imprevisível. São Paulo: Lemos Editorial; 1998.
Gaudichon B. Camille Claudel, Femme Sculpter. Poitier: Catalogue Camille Claudel; 1984.

Goodwin FK, Kay RJ. Manic-Depressive IIIness. New York: Oxford University Press; 1990.

Hill A. Art Versus Illness. London: George Allem and Unwin; 1945. Jarassé D. Rodin: La Passión du Mouvement. Paris: Terrail; 1993. Jaspers K. Genio y Locura. Madrid: Aguilar SA de Ediciones; 1956. 
Kretschmer E. Hombres Geniales. Barcelona: Editora Labor; 1953.

Maccagnani G. L'Arte psicopatologica. Rivista Sperimentale di Freniatria, Vol. LXXXII, Fasc. II. Supplemento, 1958.

Monique L. Guide du Musée Rodin. Paris: Hazan; 1984.

Pinet H. Rodin: Les Mains Du Génie. Paris: Gallimard; 1984.

Suassuna A. Iniciação à Estética. 4. ed. Recife: Ed. Universitária da UFPE; 1996.
Vallejo-Najera JA. Loucos Egrégios. Rio de Janeiro: Guanabara Dois; 1979.

Vilain J, Judrin C, Le Normand A, Pinet H, Marraud H. Rodin - Le Musée et ses Collections. Paris: Editions Scala; 1996.

Volmat R. L'Art Psychopathologique. Paris: Presses Universitaires de France; 1955 